Article

\title{
Bio-Insecticidal Potential of Nucleopolyhedrovirus and Granulovirus Mixtures to Control the Fall Armyworm Spodoptera frugiperda (J.E. Smith, 1797) (Lepidoptera: Noctuidae)
}

\author{
Paola E. Cuartas-Otálora ${ }^{1, *}$, Juliana A. Gómez-Valderrama ${ }^{1}$, Andrea E. Ramos ${ }^{1}$, \\ Gloria P. Barrera-Cubillos ${ }^{1}$ and Laura F. Villamizar-Rivero ${ }^{2}$ \\ 1 Corporación Colombiana de Investigación Agropecuaria-Agrosavia, Centro de Investigación Tibaitatá, \\ kilómetro 14 vía Mosquera-Bogotá, 250047 Cundinamarca, Colombia \\ 2 AgResearch, Forage Science, Lincoln Research Centre, Private Bag 4749, Christchurch 8140, New Zealand \\ * Correspondence: pcuartas@agrosavia.co; Tel.: +571-422-7300
}

Received: 28 May 2019; Accepted: 22 July 2019; Published: 26 July 2019

\begin{abstract}
The ability of the isolate VG008 of S. frugiperda granulovirus (SpfrGV) to enhance the infectivity of the isolate SfCOL of S. frugiperda multiple nucleopolyhedrovirus (SpfrMNPV) was evaluated on $S$. frugiperda larvae. Bioassays were performed with mixtures by using different proportions 90\%:10\% (M1), 95\%:5\% (M2) and 97.5\%:2.5\% (M3) of SfCOL:VG008, respectively. All mixtures showed higher insecticidal activity that SfCOL. The mixture M3 showed the highest enhancement of SfCOL reducing 11.40 times the Mean Lethal Concentration and $96 \mathrm{~h}$ in the Mean Time to Death. The enhancer activity of proteins derived from VG008 (GVPs) were also evaluated in mixture with SfCOL. The GVPs increased $27 \%$ larval mortality caused by SfCOL and damaged the peritrophic membrane of $S$. litura larvae, suggesting that the key point in this enhancing activity is the initial step of the larva colonization, the midgut infection. M3 was formulated and evaluated under greenhouse conditions in maize plants using different doses. The highest efficacy was obtained with the highest dose of M3 $\left(8 \times 10^{11} \mathrm{OBs} / \mathrm{ha}\right)$, which was similar to that found when formulated SfCOL was applied using an approximately twofold higher dose. The viral mixture M3 was selected as the active ingredient for developing a new biopesticide for a more efficient management of the pest in the field.
\end{abstract}

Keywords: biopesticide; enhancement; Granulovirus; Nucleopolyhedrovirus; pathogenicity; Spodoptera frugiperda; virulence

\section{Introduction}

The fall armyworm, Spodoptera frugiperda (J.E. Smith, 1797) (Lepidoptera: Noctuidae) is a polyphagous migratory pest, endemic to the western hemisphere, considered the most important pest in maize (Zea mays L) in Colombia [1] and the Americas. The control of S. frugiperda in this crop is mainly achieved using chemical insecticides, which are not specific and present high toxicity. In consequence their continued use can lead negative effects such as development of resistant populations, reduction of beneficial insects and adverse environmental impact by the accumulation of toxic residues in food chain and water and soil pollution [2].

To reduce these effects and maintain pest levels below the economic threshold, some strategies as biological control has been developed through the use of entomopathogenic viruses, mainly from Baculoviridae family or baculovirus (BV), which are viruses with high insecticidal activity and with a narrow spectrum of hosts [2]. Baculoviridae family includes insect-specific viruses with large, 
circular, dsDNA genomes between 80 to $180 \mathrm{kpb}$. The family includes four genera: Alphabaculovirus (lepidopteran-specific nucleopolyhedrovirus (NPV)), Betabaculovirus (lepidoteran-specific granulovirus (GV)), Gammabaculovirus (hymenopteran-specific NPV) and Deltabaculovirus (dipteran-specific NPV) [3].

Worldwide, different isolates of Spodoptera frugiperda Nucleopolyhedrovirus (SpfrMNPV) have been used for biological control of fall armyworm, with efficacies higher than 80\% [4-6], demonstrating its potential to control the pest. For developing efficient biopesticides to control S. frugiperda, some strategies of insecticidal activity enhancement have been evaluated. Within these approaches, biological enhancers have demonstrated the ability to improve the insecticidal activity of BVs increasing the host susceptibility and decreasing the time of action [7].

In this sense, in previous works two baculoviruses-a nucleopolyhedrovirus and a granulovirus -were isolated from $S$. frugiperda larvae collected in a pasture crop in Colombia, suggesting a possible natural co- infection [8]. The SpfrMNPV (SfCOL) and the SpfrGV (VG008) were characterized morphologically, biologically and molecularly [8-11]. The gene content showed that SpfrGV VG008 possesses encoding sequences for virulence factors such as 3 chitinases and 2 enhancins [11]; this observation offers the possibility of postulating the use of this granulovirus as an enhancing factor for bio-insecticides based on SpfrMNPV for the control of S. frugiperda.

Early studies on other lepidopteran pest showed that mixtures between NPVs and GVs significantly increased the infectivity and virulence of the NPV over its natural host [12]. This effect was attributed to the virulence factors as proteins such enhancins and chitinases $[7,13]$. This enhancer effect has been related with the affinity of these proteins for insect intestinal mucin and chitin, proteins associated with the peritrophic membrane (PM), the first barrier of defense in lepidopteran larvae. This interaction increases the susceptibility of the insect host to viral infection by altering the PM permeability [7].

The aim of the present work was to study the potential of SpfrGV (VG008) to enhance the insecticidal activity of SpfrMNPV (SfCOL) against S. frugiperda larvae, in order to select the most virulent active ingredient to develop a novel a biopesticide to control the fall armyworm.

\section{Materials and Methods}

\subsection{Insect Rearing}

Larvae of $S$. frugiperda were obtained from a laboratory colony established from eggs and larvae collected in a maize crop located at Tolima (Colombia). This colony was refreshed every six months (F6) by introducing insects collected in the field. Larvae were maintained at $25{ }^{\circ} \mathrm{C}$ and $60 \%$ relative humidity (RH), under a natural photoperiod of 12:12 h (light: dark) and were fed with a wheat germ-based semi-synthetic diet [14].

\subsection{Virus Production, Purification and Quantification}

Two Colombian isolates of $S$. frugiperda baculovirus were used, one SpfrMNPV denominated SfCOL and one of SpfrGV denominated VG008, obtained from infected larvae of S. frugiperda found in a pasture at department of Córdoba (Colombia) [8]. Production was made separately for each viral isolate by inoculating larvae of S. frugiperda (neonate larvae for NPV and second instar larvae for GV) using the droplet feeding method [15]. For this purpose, starved larvae of S. frugiperda were orally inoculated with a suspension containing $10^{6}$ occlusion bodies $(\mathrm{OBs}) / \mathrm{mL}$, then larvae were individually maintained at $25^{\circ} \mathrm{C}$ and $60 \% \mathrm{RH}$, under a natural photoperiod of 12:12 h (light:dark) until death. OBs were extracted from dead diseased larvae by homogenizing cadavers in $0.1 \%(w / v)$ sodium dodecyl sulphate (SDS) solution and purified by filtration and differential centrifugations. GVs suspensions were quantified by absorbance measurements at $280 \mathrm{~nm}$ and extrapolated from a standard curve [9], and NPVs suspensions were quantified using a Neubauer hemocytometer (Hawksley Ltd., Lancing, UK) under a light microscopy at $40 \times$. 


\subsection{Evaluation of Mixtures between Granulovirus and Nucleopolyhedrovirus}

The Mean Lethal Concentration $\left(\mathrm{LC}_{50}\right)$ of three mixtures prepared using different ratio SfCOL: VG008 were determined: 90\% SfCOL: 10\% VG008 (M1), 95\% SfCOL: 5\% VG008 (M2) and 97.5\% SfCOL: $2.5 \%$ VG008 (M3). Each mixture was adjusted to five total concentrations of viral particles (CTot): $1 \times 10^{4}, 1 \times 10^{5}, 1 \times 10^{6}, 1 \times 10^{7}$ and $1 \times 10^{8} \mathrm{OBs} / \mathrm{mL}$. Suspensions individually containing SfCOL and VG008 were prepared and adjusted to the same five concentrations. All final suspensions contained $4 \%(w / v)$ sucrose and $1 \%(w / v)$ blue food dye Tuska ${ }^{\circledR}$ (blue No. 1 and blue No. 2). Pathogenicity and virulence were determined on S. frugiperda larvae by using the droplet feeding method [15]. The absolute control corresponded to larvae without treatment and the treated control corresponded to larvae fed only with sucrose and dye solution without containing OBs.

Three groups of $10 \mathrm{~s}$ instar larvae ( 3 replicates) starved for $12 \mathrm{~h}$ were inoculated with each viral suspension and individually transferred into $14 \mathrm{~mL}$ cups provided with natural diet (disinfected leaves of Ricinus communis) and reared at $25^{\circ} \mathrm{C}$ and $60 \% \mathrm{RH}$, under a natural photoperiod of 12:12 $\mathrm{h}$ (light:dark).

Larval mortality was recorded daily for 15 days post-inoculation. Dead larvae were macerated in $1 \mathrm{~mL}$ of sterilized water and vortexed to mix, samples were then observed at $40 \times$ under light microscopy. Experimental design was completely random, with three replicates per treatments and the complete experiment was performed on three different occasions. Mortality data of the treatments were corrected with the mortality data from the control treatment. The $\mathrm{LC}_{50}$ and $\mathrm{LC}_{90}$ of each viral mixture were determined by using the logit regression of the Generalized Linear Interactive Modeling program (GLIM) [16]. For the comparison of $\mathrm{LC}_{50}$ values, parallelism of the calculated lines was checked by using the parallel-line assay option.

Relative potency (RP) for each mixture was determined according with SfCOL and calculated using the following formula: $\mathrm{RP}=\mathrm{LC}_{50} \mathrm{SfCOL} / \mathrm{LC}_{50}$ mixture. Virulence expressed as the Mean Time to Death (MTD) was calculated by using the mortality data obtained during the pathogenicity bioassays with the concentration of $1 \times 10^{7} \mathrm{OBs} / \mathrm{mL}$. Time-mortality data were subjected to Weibull survival analysis using the GLIM program [16].

\subsection{Assessment of Enhancer Activity of Proteins Derived from VG008}

Proteins derived from VG008 (GVPs) were prepared by dissolving the OBs in $\mathrm{Na}_{2} \mathrm{CO}_{3} 0.5 \mathrm{M}$ $(\mathrm{pH} 10)$ at $37^{\circ} \mathrm{C}$ for $2 \mathrm{~h}$. Then, the undissolved material was pelleted by centrifugation at $13,000 \mathrm{~g}$ for $20 \mathrm{~min}$. The supernatant containing GVPs was collected and the proteins were electrophoresed in 14\% SDS-PAGE with Coomassie blue staining.

To evaluate the enhancer activity of GVPs a bioassay was performed in S. frugiperda second instar larvae by using the droplet feeding method [15] as described above. Larvae were treated with the mixture containing SfCOL $\left(1 \times 10^{6} \mathrm{OBs} / \mathrm{mL}\right)$ and VG008 GVPs $(200 \mu \mathrm{g} / \mathrm{mL})$. Additionally, four control treatments were set up: i) Larvae fed only with the GVPs $(200 \mu \mathrm{g} / \mathrm{mL})$; ii) Larvae fed only with SfCOL $\left(1 \times 10^{6} \mathrm{OBs} / \mathrm{mL}\right)$; iii) Larvae fed with SfCOL diluted in $\mathrm{Na}_{2} \mathrm{CO}_{3} 0.5 \mathrm{M}\left(1 \times 10^{6} \mathrm{OBs} / \mathrm{mL}\right)$ prepared immediately before inoculation: iiii) Non-treated larvae (Control). Larval mortality was recorded 10 days post-inoculation. Mortality values recorded in the treatments were corrected with the mortality in the control using the Schneider-Orelli formula to express the result as percentage of efficacy (\%) [17]. Results were analyzed with one-way ANOVA and Tukey test (95\%) using Statistix 8.0.

To study the effect of the GVPs over the integrity of larval peritrophic membrane, Spodoptera litura four instar larvae were fed with GVPs $(500 \mu \mathrm{g} / \mathrm{mL})$ and processed $4 \mathrm{~h}$ post-feeding. For that the complete guts were dissected from the larvae and fixed in glutaraldehide in PBS $(2.5 \%)$ by $24 \mathrm{~h}$ at $4{ }^{\circ} \mathrm{C}$. After that, the PMs were extracted and washed with ultrapure water, followed by dehydration with ethanol $70 \%$ and $100 \%$. The PMs were cut and the contents removed before sputtering with palladium. Observations and images were made on a scanning electron microscope JEOL JSM IT-300 (JEOL Ltd., Tokyo, Japan). 


\subsection{Characterization of Selected Mixture Formulated as Wettable Powder}

Mixture M3 (97.5\% of SfCOL $+2.5 \%$ of VG008) selected for its higher insecticidal activity was formulated as a wettable powder (WP) and then characterized following the methodologies described by [6] and [18].

\subsubsection{Moisture Content}

Three samples of $0.5 \mathrm{~g}$ were tested in a moisture analyzer OHAUS MB 45 at $100{ }^{\circ} \mathrm{C}$ for $10 \mathrm{~min}$.

\subsection{2. $\mathrm{pH}$}

Three samples of $0.1 \mathrm{~g}$ were resuspended in sterile distilled water and $\mathrm{pH}$ determination was made with a calibrated potentiometer Consort C931.

\subsubsection{Contaminants Content}

Three sample of $0.1 \mathrm{~g}$ were suspended in $0.5 \%(v / v)$ Tween 80 solution. Ten-fold dilutions were prepared, and $100 \mu \mathrm{L}$ of each dilution were plated on Petri dishes containing Potato Dextrose Triton Agar (PDTA) medium and incubated five days at $26^{\circ} \mathrm{C}$ to evaluate contaminant mold; on Yeast Malt Agar (YMA) plates incubated for two days at $26^{\circ} \mathrm{C}$ to evaluate contaminant yeasts and on Nutrient Agar (NA) plates incubated for $24 \mathrm{~h}$ at $28^{\circ} \mathrm{C}$ to determine the number of contaminant bacteria. Results were expressed as average number of colony forming units per gram (CFU/g) [19].

\subsubsection{Insecticidal Activity in Laboratory}

S. frugiperda neonate larvae were inoculated with the viral mixture (formulated and unformulated) following the droplet feeding method [15]. Treatments were adjusted to a total concentration of $2 \times 10^{7} \mathrm{OBs} / \mathrm{mL}$ containing $4 \%(w / v)$ sucrose and $1 \%(w / v)$ blue food dye Tuska ${ }^{\circledR}$ (blue No. 1 and blue No. 2). Control treatments consisted in a treated control where larvae were inoculated with the sugar-colorant solution without viruses and an absolute control with non-treated larvae. Experimental design was completely random with three replicates of 10 larvae per treatment (30 larvae/treatment). Larvae were maintained at $25{ }^{\circ} \mathrm{C}$ and the number of surviving insects was recorded seven days after inoculation. Mortality values were determined and treatment mortality was corrected with the value in the control (larvae without treatment) by using the Schneider-Orelli equation [17].

\subsubsection{Photostability}

Stability against ultraviolet (UV) radiation was determined following the methodology described in [20]. Mixture M3 and SfCOL formulated and unformulated were reconstituted in sterile water adjusting a final concentration of $2 \times 10^{7} \mathrm{OBs} / \mathrm{mL}$. Samples of $20 \mu \mathrm{L}$ of each viral suspension were placed in four continuous microplate wells (each treatment in one row). Before irradiation, the first well of each row was covered with aluminum film in order to protect it against UV light, corresponding these samples to non-irradiated treatments. Then, the microplate was located inside a chamber at $10 \mathrm{~cm}$ distance from a Repti Glo 8.0 lamp which simulates solar UV radiation (33\% of UVA and 8\% of UVB) and irradiated for $6 \mathrm{~h}$. Each $2 \mathrm{~h}$ after irradiation was initiated, the next well of each row was covered with aluminum film, corresponding to a different irradiation time. After the exposure to UV light, all samples were collected and evaluated for viral activity in a bioassay following the methodology previously described.

\subsection{Greenhouse Trial to Select Application Dose}

Insecticidal activity of formulated mixture M3 was evaluated on maize plants under glass greenhouse conditions at the Tibaitatá Research Center, Mosquera, Cundinamarca (Colombia) $\left(4^{\circ} 41^{\prime} 45^{\prime \prime} \mathrm{N}, 74^{\circ} 12^{\prime} 12^{\prime \prime} \mathrm{W}\right)$. Maize seeds (ICA 508) were planted individually in 16 ounces pots with soil. Thirty days after plants emergence when the plants had around $20 \mathrm{~cm}$ height and three true leaves, 
treatments were applied. Each plant was sprayed with $1 \mathrm{~mL}$ of the respective treatment by using a manual atomizer and 15 min after application when leaves were dry, three second instar larvae of $S$. frugiperda were placed on each plant.

Treatments were the formulated mixture M3 adjusted to five different doses (Table 1) and formulated SfCOL adjusted to its recommended dose [8]. Control treatment consisted in non-treated plants.

Table 1. Treatments evaluated in the greenhouse trial against $S$. frugiperda.

\begin{tabular}{cccc}
\hline \multirow{2}{*}{ Treatments } & $\begin{array}{c}\text { Total Dose } \\
\text { OBs/ha }\end{array}$ & \multicolumn{2}{c}{ Viral Mixture Composition } \\
\cline { 3 - 4 } & & $\begin{array}{c}\text { NPV OBs } \\
\mathbf{( 9 7 . 5 \% )}\end{array}$ & $\begin{array}{c}\text { GV OBs } \\
\mathbf{( 2 . 5 \% )}\end{array}$ \\
\hline M3 Dose 1 & $5.0 \times 10^{10}$ & $4.9 \times 10^{10}$ & $1.2 \times 10^{9}$ \\
M3 Dose 2 & $1.0 \times 10^{11}$ & $9.8 \times 10^{11}$ & $2.4 \times 10^{9}$ \\
M3 Dose 3 & $2.0 \times 10^{11}$ & $2.0 \times 10^{11}$ & $4.9 \times 10^{9}$ \\
M3 Dose 4 & $4.0 \times 10^{11}$ & $3.9 \times 10^{11}$ & $9.8 \times 10^{9}$ \\
M3 Dose 5 & $8.0 \times 10^{11}$ & $7.8 \times 10^{11}$ & $2.0 \times 10^{10}$ \\
SfCOL-F & $1.5 \times 10^{12}$ & $1.5 \times 10^{12}$ & - \\
\hline
\end{tabular}

Experimental design was randomized complete blocks, with three replicates per treatment and experiment was repeated twice in different times. Each experimental unit consisted of ten plants, with a total of 30 plants per treatment. Four days after application, larvae were recovered, counted and individually placed in plastic cups with natural diet ( $R$. communis leaves). Larvae were reared at $25^{\circ} \mathrm{C}$ and the number of surviving insects was recorded during the next 15 days. Only individuals with viral infection symptoms were recorded to determine mortality values, which were corrected with the mortality in the control (larvae without treatment) by using the Schneider-Orelli equation [17].

\section{Results}

\subsection{Mixtures between Granulovirus and Nucleopolyhedrovirus}

To determine an enhancer effect of VG008 on biological activity of SfCOL against second instar larvae of $S$. frugiperda, a dose-response bioassay with several mixtures was conducted. Larvae infected with VG008 slowly developed the disease and survived for several weeks, developing the typical symptoms of a GV infection, i.e., loss of appetite, decrease in mobility, yellowish-white coloration and a swollen larva body due to the accumulation of occlusion bodies in the infected tissues, with non-ruptured integument after dead (Figure 1A). Larvae infected with SfCOL rapidly developed symptoms of NPV infection with brownish color, waxy appearance and liquefaction of the cadaver (Figure 1B). Most larvae infected with the viral mixtures exhibited symptoms of NPV disease and high polyhedral production in the cadavers was confirmed by examination under light microscopy $(40 \times)$ (Figure 1C,D).

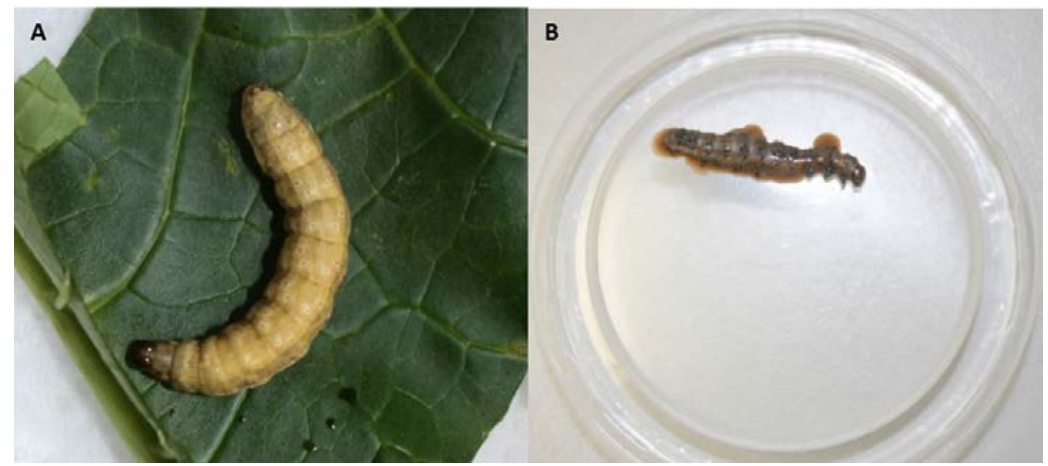

Figure 1. Cont. 


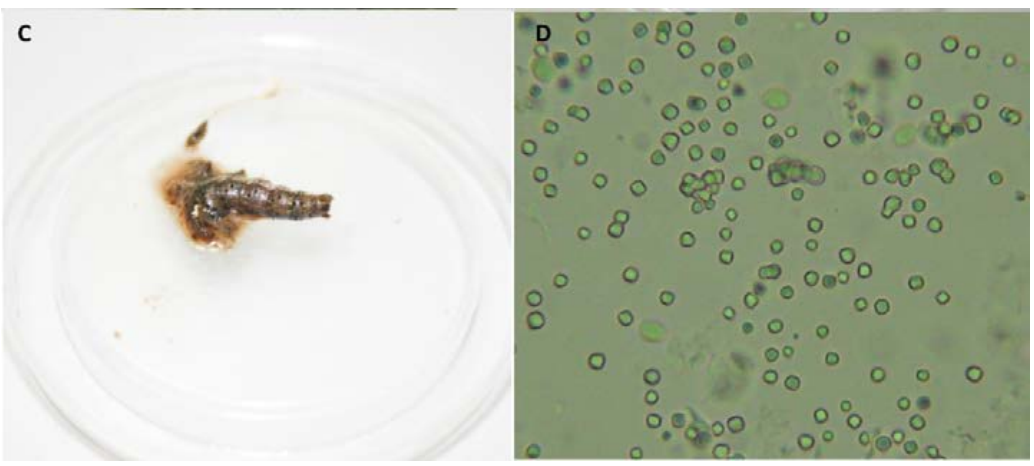

Figure 1. Larvae of $S$. frugiperda infected with (A) VG008 at 29 days post-infection, (B) SfCOL at 7 days post-infection, (C) mixture M3 after 5 days post-infection, and (D) nucleopolyhedrovirus occlusion bodies observed in macerates of $S$. frugiperda larva infected with mixture M3, examined under light microscopy $(40 \times)$.

Generated logit regressions showed a direct relationship between dose and mortality. The $\mathrm{LC}_{50}$ value for SfCOL was $2.05 \times 10^{5} \mathrm{OBs} / \mathrm{mL}$, which not significantly differed from the $\mathrm{LC}_{50}$ value for VG008 (Table 2). The $\mathrm{LC}_{50}$ values for mixtures ranged from $1.80 \times 10^{4} \mathrm{OBs} / \mathrm{mL}$ for $\mathrm{M} 3$ to $5.87 \times 10^{4} \mathrm{OBs} / \mathrm{mL}$ for M2 with no significant differences between them (Table 2). However, all mixtures presented significantly lower $\mathrm{LC}_{50}$ than SfCOL $(P<0.001)$, indicating higher pathogenicity (Table 2$)$.

Table 2. Estimated $\mathrm{LC}_{50}$ values, relative potencies (RP) and mean time to death (MTD) values of SfCOL and VG008 mixtures in S. frugiperda second instar larvae.

\begin{tabular}{|c|c|c|c|c|c|c|c|c|}
\hline \multirow{2}{*}{ Treatment } & \multirow{2}{*}{$\begin{array}{c}\mathrm{LC}_{50} \\
\text { (OBs/mL) }\end{array}$} & \multicolumn{2}{|c|}{ Fiducial Limits (95\%) } & \multirow{2}{*}{$\mathbf{R P}$} & \multirow{2}{*}{$P$ Value } & \multirow{2}{*}{ MTD (Days) } & \multicolumn{2}{|c|}{ Fiducial Limits $(95 \%)$} \\
\hline & & Low & High & & & & Low & High \\
\hline SfCOL & $2.05 \times 10^{5}$ & $1.08 \times 10^{5}$ & $3.81 \times 10^{5}$ & - & - & 7 & 7 & 8 \\
\hline VG008 & $4.65 \times 10^{5}$ & $1.91 \times 10^{5}$ & $1.13 \times 10^{6}$ & 0.44 & 0.110 & 29 & 25 & 33 \\
\hline M1 & $4.30 \times 10^{4}$ & $2.51 \times 10^{4}$ & $7.17 \times 10^{4}$ & 4.76 & $<0.001$ & 4 & 4 & 4 \\
\hline M2 & $5.87 \times 10^{4}$ & $3.49 \times 10^{4}$ & $9.77 \times 10^{4}$ & 3.49 & $<0.001$ & 4 & 4 & 4 \\
\hline M3 & $1.80 \times 10^{4}$ & $1.01 \times 10^{4}$ & $3.09 \times 10^{4}$ & 11.40 & $<0.001$ & 3 & 3 & 4 \\
\hline
\end{tabular}

Logit regressions were fitted using GLIM program. A test for parallelism for all treatments was not rejected $(P>$ 0.05). $(X 2=4.66$, d.f. $=3)$. Common slope $( \pm S E)$ of $0.72 \pm 0.08$.

Parallelism of regression lines for the mixtures and SfCOL were determined to calculate the RP (Table 2). All combinations of VG008 and SfCOL were significantly more potent than the SfCOL used alone. Mixtures M1 and M2 were approximately fourfold more pathogenic than SfCOL. The most potent mixture was M3 (VG008 2.5\% and SfCOL 97.5\%), being approximately 12-fold more pathogenic than SfCOL.

Regarding the virulence, MTD of all mixtures ranged between 3 and 4 days, values significantly lower than the obtained for SfCOL and VG008 evaluated individually, with 7 and 29 days, respectively. Although differences were not detected between all mixtures, the lowest MTD was obtained with the mixture M3 (Table 2).

\subsection{Enhancer Activity of Proteins Derived from VG008}

Feeding S. frugiperda L2 larvae with $1 \times 10^{6}$ SpfrMNPV OBs/mL resulted in $73.3 \%$ efficacy (Figure 2). When the same viral suspension was mixed with GVPs adjusted to a final concentration of $200 \mu \mathrm{g} / \mu \mathrm{L}$, the efficacy increased to $93.3 \%$ (Figure 2 ). The differences are statistically significant $(P<0.001)$. Non-significantly differences were found between efficacy obtained with SfCOL and SfCOl mixed with $\mathrm{Na}_{2} \mathrm{CO}_{3}(71.1 \%)$ and efficacy caused by the GVPs was significantly lower than that obtained with all the other treatments (11.1\%) (Figure 2). Mortality was not observed with the non-treated larvae. 


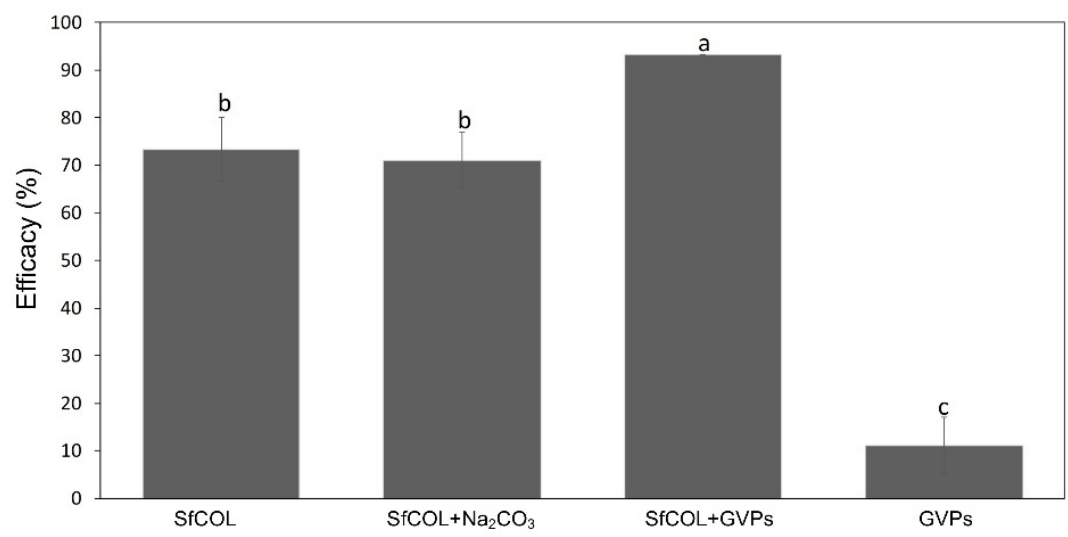

Figure 2. Effect of SfCOL and GVPs on S. frugiperda larvae mortality. Treatment mortalities were corrected with mortality in the control to estimate efficacy. Bars labelled with the same letters did not differ significantly according to Tukey test (95\%). Error bars indicate the standard deviation (SD).

With the aim to demonstrate the presence of possible proteins enhancing the NPV, the proteins released after alkaline treatment of VG008 OBs were electrophoresed. The SDS-PAGE of GVPs showed different bands corresponding to estimated sizes of viral proteins previously reported in the complete genome of VG008 [11,21]

The peritrophic membrane of $S$. litura larvae fed with GVPs showed damages in the structure (Figure 3). The surface presented several small holes $(200-600 \mathrm{~nm}$ ), which seem to be joining together at the most affected regions to form larger holes up to $2 \mu \mathrm{m}$.

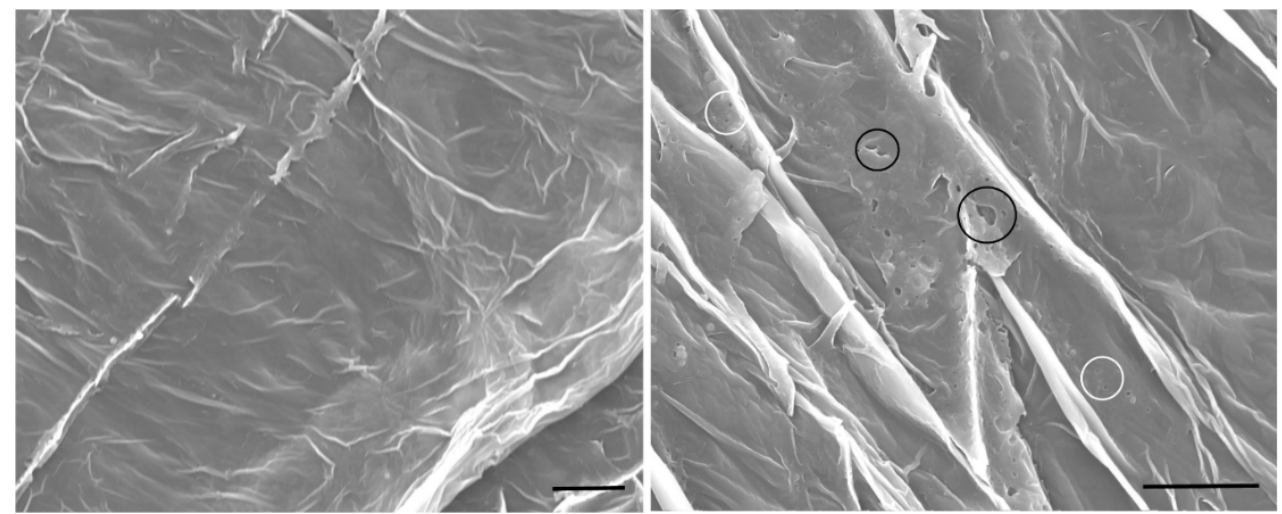

Figure 3. Scanning electron micrographs showing the effect of GVPs on S. litura peritrophic membrane (PM). (Left) PM of control larvae. (Right) PM of larvae treated with GVPs. White circles indicate small holes and black circles indicate larger holes. The black line corresponds to $10 \mu \mathrm{m}$.

\subsection{Characterization of Selected Mixture Formulated as Wettable Powder}

The characteristics of the prototype based on viral mixture M3 formulated as WP are presented in Table 3. Although there are no quality standards for baculovirus products that are internationally accepted [22], the results were compared with acceptance limits established in [6] for formulated SfCOL, to ensure that the formulation does not affect the characteristics of the viral mixture.

Physicochemical properties as moisture content and $\mathrm{pH}$ were within the reference limits, with values of 2.30 and 7.67, respectively. The bacterial and fungal contaminating load also met specifications, with values $<10^{7} \mathrm{CFU} / \mathrm{g}$. The efficacy evaluated in neonate larvae of $S$. frugiperda was $96.7 \%$ for M3 formulated as WP, equal value to that obtained with the unformulated viral mixture (Table 3). 
Table 3. Quality parameters of mixture M3 (97.5\% of SfCOL + 2.5\% of VG008) formulated as WP.

\begin{tabular}{ccccc}
\hline Parameter & Mean & SD & Acceptance Limits & Reference \\
\hline Moisture content (\%) & 2.30 & 0.16 & $<5$ & \\
pH & 7.67 & 0.04 & $<8$ & \\
\hline Bacteria content (CFU/g) & $2.43 \times 10^{6}$ & 0.07 & & \\
Mold content (CFU/g) & $7.16 \times 10^{5}$ & 0.12 & $<5 \times 10^{8}$ & \\
Yeast content (CFU/g) & $<1 \times 10^{4}$ & 0 & & \\
\hline Efficacy (\%) & 96.7 & 5.8 & $\geq 80 \%$ & \\
\hline
\end{tabular}

Regarding photostability, the initial efficacies for non-irradiated viruses were $96.7 \%$ and $100 \%$ for mixture M3 and SfCOL respectively, with non-statistical differences between them or between formulated and unformulated viruses $(F=0.67, d f=3,8, P=0.5957)$ (Table 4). However, the efficacy of unformulated viruses progressively reduced as the irradiation time increased. The unformulated viral mixture M3 was rapidly and significantly inactivated after $2 \mathrm{~h}$ of irradiation, while the formulated mixture was stable and maintained its insecticidal activity through the $6 \mathrm{~h}$ of irradiation time with values above $96 \%$ of efficacy (Table 4). Similar result was obtained for SfCOL with $100 \%$ of efficacy when virus was formulated and irradiated for $6 \mathrm{~h}$ and a significant $90 \%$ drop in efficacy of unformulated virus after $2 \mathrm{~h}$ of $\mathrm{UV}$-exposure $(F=18.4, d f=15,32, P=0.0000)$. The original activity remaining (OAR) of unformulated M3 and SfCOL after 2 h UV-irradiation was $6.9 \%$ and $10 \%$ respectively, without differences between treatments suggesting that both active ingredients (unformulated viruses) are equally susceptible to UV-radiation (Table 4). The OAR values of formulated viruses were significantly higher $(F=16.4, d f=11,24, P=0.0000)$ than those obtained with unformulated treatments at all evaluated times for SfCOL and the viral mixture M3 (Table 4).

Table 4. Susceptibility of unformulated and formulated mixture M3 to ultraviolet radiation.

\begin{tabular}{cccccc}
\hline \multirow{2}{*}{ Parameter } & \multirow{2}{*}{ Irradiation Time (h) } & \multicolumn{4}{c}{ Treatments } \\
\cline { 3 - 6 } & & M3 F & M3 UF & SfCOL F & SfCOL UF \\
\hline \multirow{2}{*}{ Efficacy (\%) } & 2 & $96.7 \mathrm{a}$ & $96.7 \mathrm{a}$ & $100.0 \mathrm{a}$ & $100.0 \mathrm{a}$ \\
& 4 & $100.0 \mathrm{a}$ & $6.7 \mathrm{~b}$ & $100.0 \mathrm{a}$ & $10.0 \mathrm{~b}$ \\
& 6 & $96.7 \mathrm{a}$ & $3.3 \mathrm{~b}$ & $100.0 \mathrm{a}$ & $6.7 \mathrm{~b}$ \\
OAR (\%) & 2 & $100.0 \mathrm{a}$ & $6.7 \mathrm{~b}$ & $100.0 \mathrm{a}$ & $13.3 \mathrm{~b}$ \\
\hline \multirow{2}{*}{ Inactivation (\%) } & 4 & $100.0 \mathrm{a}$ & $6.9 \mathrm{~b}$ & $100.0 \mathrm{a}$ & $10.0 \mathrm{a}$ \\
& 6 & $100.0 \mathrm{a}$ & $3.4 \mathrm{~b}$ & $100.0 \mathrm{a}$ & $6.7 \mathrm{a}$ \\
& 2 & $100.0 \mathrm{a}$ & $6.9 \mathrm{~b}$ & $100.0 \mathrm{a}$ & $13.3 \mathrm{a}$ \\
\hline
\end{tabular}

The statistical analysis was performed independently for each variable. Treatments with the same letter do not present significant differences according to multiple Tukey's test (95\%).

\subsection{Greenhouse Trial to Select Application Dose}

Four days after infestation of the maize plants with larvae, the typical signs of damage caused by $S$. frugiperda were observed in all maize plants, such as translucent spots and small, irregular perforations. Larval mortality in the untreated plants (control treatment) was $9.4 \%$, a significantly lower value $(F=41.6, d f=6,35, P=0.0000)$ compared with all the viral treatments, except that obtained with the lowest dose of the M3 mixture $\left(5.0 \times 10^{10} \mathrm{OBs} / \mathrm{ha}\right)($ Table 5$)$.

Mortalities and efficacies obtained with the viral treatments were statistically different between the evaluated doses $(F=26.3, d f=5,30, P=0.0000)$ (Table 5$)$, showing a directly proportional relationship between the dose and the mortality. The highest efficacy was obtained with the highest dose of mixture 
M3 $\left(8 \times 10^{11} \mathrm{OBs} / \mathrm{ha}\right)$, which was similar to that found when formulated SfCOL (SfMNPV) was applied using an approximately twofold higher dose (Table 5).

Table 5. Mortality of second-instar larvae of S. frugiperda under greenhouse conditions after the application of mixture M3 formulated as WP.

\begin{tabular}{cccc}
\hline Treatment & $\begin{array}{c}\text { Total Dose } \\
\text { OBs/ha }\end{array}$ & Mortality (\%) & Efficacy (\%) \\
\hline Control & - & 9.4 & - \\
M3 Dose 1 & $5.0 \times 10^{10}$ & 28.6 & $21.2 \mathrm{c}$ \\
M3 Dose 2 & $1.0 \times 10^{11}$ & 37.8 & $31.3 \mathrm{c}$ \\
M3 Dose 3 & $2.0 \times 10^{11}$ & 62.6 & $58.7 \mathrm{~b}$ \\
M3 Dose 4 & $4.0 \times 10^{11}$ & 67.4 & $64.0 \mathrm{~b}$ \\
M3 Dose 5 & $8.0 \times 10^{11}$ & 91.5 & $90.6 \mathrm{a}$ \\
SfCOL-F & $1.5 \times 10^{12}$ & 91.7 & $90.8 \mathrm{a}$ \\
\hline
\end{tabular}

Treatments with the same letter do not present significant differences according to Tukey's test (95\%).

\section{Discussion}

In this study, the increase of insecticidal activity of SpfrMNPV by adding low ratio proportions of SpfrGV over second instar larvae of $S$. frugiperda was studied. All larvae infected with viral mixtures (SfCOL + VG008) showed the typical symptoms of polyhedrosis disease, such as a characteristic shiny-oily appearance and extremely fragile tegument, which rupturing releases a fluid filled with virus particles. The combination of both viruses increased efficacy, and in the dead larva was possible to observe NPV OBs, but not GV OBs.

Mixture M3 (97.5\% of SfCOL and 2.5\% of VG008) presented the highest relative potency and virulence with the lowest MTD and significantly higher pathogenicity than observed with the wild isolates SfCOL and VG008 (Table 2), demonstrating that interaction between the viruses lead to an increase in efficacy. Additionally, when the GV proteins are added, this increase is maintained. Accordingly, it seems that the key point is the initial step of the larva colonization, the midgut infection. However, further histopathological studies are needed to elucidate the changes in the infection course caused by the mixture of VG008 and SfCOL.

Similar researches have reported different viral interactions between GVs and NPVs that improve the viral pathogenicity and virulence. For example mixtures between a GV and a NPV of S. litura showed a RP of 6.5 with respect to the pathogenicity of the NPV alone [23], the mixture of a GV and a NPV of Spodoptera exigua and a GV of Xestia c-nigrum and a NPV of Mamestra brassicae which presented a RP of 10 with respect to the $L_{50}$ of NPVs used alone [24-26]) and the mixture between a GV of S. frugiperda and a NPV of Lymantria dispar, being this mixture 13 times more pathogenic that the NPV individually used [27].

The mixture M3 presented the lowest MTD, with a value of $72 \mathrm{~h}$ (3 days), which means $96 \mathrm{~h}$ reduction in comparison with SfCOL and $624 \mathrm{~h}$ reduction in comparison with VG008. These results are higher than those achieved in other cases of mixtures of GVs and NPVs. For example, the mixture between the GV of Trichoplusia ni and the NPV of Anticarsia gemmatalis, the GV of X. c-nigrum and the NPV of M. brassicae and mixture between the GV of Helicoverpa armigera and the NPV of L. dispar, presented MTD reductions of 2, 48 and $55 \mathrm{~h}$ respectively [25-29]. Potential virulence factors of GV associated with an enhancer effect over NPV has been described, these factors include proteins contained in the occlusion bodies of different granulovirus isolates $[23,26,27,30,31]$. For example, alkaline soluble proteins of capsules (GVPs) of X. c-nigrum GV mixed with M. brassicae NPV, resulted in a significant increase of NPV infections (from 53\% to 66\%) under field conditions [30]. This enhancement has been attributed to proteins as enhancins and chitinases but also proteins with binding chitin capacity as per os infection factor 2 or GP37 [7,29,31-33]. These kinds of proteins can digest the proteins of the 
PM from infected insects by altering its structural integrity and increasing its permeability, allowing a faster entry of the viral particles into the cells improving the infection process [7,29,34,35].

It had been suggested that the coinfection of H. armigera GV and Helicoverpa zea SNPV over H. zea larva could inhibit the NPV replication by outcompeting [36]. In the SfCOL and SpfrGV coinfection, the dead larva presented typical symptoms of NPV disease and no evidence of GV replication was observed, suggesting that enhancement of NPV was a consequence of action of GV proteins contained in the OBs. The proteins derived from VG008 OBs increased 27\% the larvae mortality caused by SfCOL NPV, demonstrating that they are responsible for this enhancing activity. Several studies using recombinants proteins have also demonstrated the enhancer activity of these proteins in different granulovirus coinfection $[13,25,35,37]$.

The peritrophic membrane of most lepidopteran insects (type I) is a layer formed by chitin, mucopolysaccharides and proteins that protect the midgut epithelium against abrasive particles, digestive enzymes and pathogens [38]. This membrane has pores ranging between 21-29 $\mathrm{nm}$ [39] which allow a selective movement of small molecules [38]. PMs of S. litura larvae fed with GVPs of VG008 showed a damaged structure exhibiting the formation of different size pores that reached up to $2 \mu \mathrm{m}$ in the most affected areas, suggesting the enzymatic action of viral enhancing factors or enhancins that are involved in degradation of mucin II in PMs [12]. The genome of VG008 contains enhancins vef2 (ORF127) and vef4 (ORF132) genes that encodes 867 and 857 amino acids (aa) proteins respectively with predicted weights close to $99.8 \mathrm{kDa}$ [11], which were observed in SDS-PAGE and are homologous of those of H. armigera GV and X. c-nigrum GV enhancins, previously reported as enhancers of NPVs.

On the other hand, the enhancing action of chitin-binding proteins from granuloviruses that do not encode enhancin homologous proteins have been described, for example Epinotia aporema GV [31]. In this case, the GP37 protein seems to have a role in the disruption of PM by its chitin-binding properties [32]. The VG008 genome possesses chitinase-1 (ORF010), chitinase-2a (ORF071) and chitinase-2b (ORF072) and chitinase-2c (ORF134) smaller than baculoviral chitinases, but all of them with chitin-binding type-2 domains [11], which could act over the chitin of PMs. The results suggest that enhancer activity of proteins derived from occlusion bodies of S. frugiperda granulovirus VG008 on the infectivity of SpfrNPV SfCOL was due to the presence of enhancins and chitin-binding proteins that act over mucin II and chitin in the peritrophic membrane causing formation of holes that could ease the access of NPV virions to the epithelial cells of midgut and possibly other pathogens and digestive enzymes.

The prototype formulation using the mixture M3 presented adequate quality characteristics, for example the low moisture that will prevent the development of contaminants and favors the stability of the product during storage by reducing the microbial metabolism [40]. Likewise, the neutral $\mathrm{pH}$ guarantees the stability of viral particles because alkaline $\mathrm{pH}$ triggers the dissolution of OBs and the release of occluded virions [41]. Furthermore, [40] recommend that dry powder formulations should not exceed a maximum of non-pathogen contaminants of $5 \times 10^{8} \mathrm{CFU} / \mathrm{g}$. Baculovirus-based formulations with high level of contaminants usually present losses in virulence because the high metabolic activity of contaminating microorganisms that change the $\mathrm{pH}$ and cause the degradation of occlusion bodies $[40,42]$ Therefore, the content of contaminants found in the WP-formulation based on mixture M3 can be considered low and could contribute to extend the shelf-life of the stored product.

Formulated and unformulated mixture M3 presented the same efficacy against S. frugiperda larvae, suggesting that the formulation process did not affect the biological activity of viral mixture. It should be noted that the insecticidal activity was above the minimum limit established for this type of products $(>80 \%)$ [6], complying with the quality standards suggested to ensure high effectiveness in field applications.

The WP-formulation protected the viral particles against the adverse effects of UV-B radiation, due to the polymeric coating achieved by the microencapsulation process with Eudragit ${ }^{\circledR}$ S100, as previously demonstrated in [6]. The formulated virus presented $79 \%$ efficacy and $14 \%$ inactivation after six hours of irradiation with a Repti Glo 8.0 lamp that simulates sunlight, while the unformulated 
virus drastically reduced its efficacy to $46 \%$. The photo-stabilizer effect of this microencapsulated formulation was also evidenced in the present work with the viral mixture M3, demonstrating its efficiency to protect different viral active ingredients against the solar radiation. Solar radiation has been considered the most critical environmental factor for the survival of baculoviruses in the field, where the spectrum of ultraviolet light below $390 \mathrm{~nm}$ is responsible for the gradual inactivation of the virus $[43,44]$.

Regarding the dose selected under greenhouse conditions, in a previous work [6] selected $1.5 \times 10^{12} \mathrm{OBs} / \mathrm{ha}$ as the effective dose for field applications of the biopesticide based on SfCOL, which was used in the present work. Results suggested that changing the active ingredient of this developed WP-biopesticide from using SfCOL alone to using the mixture M3 could lead around 50\% reduction in the minimum effective dose for field applications, which could contribute to overcome the limitations related to the costs of in vivo viral production and in this way increase the economic feasibility of this product. The reduction in the dose confirms the enhancing effect of GV on NPV infection, even under in plant conditions. Moreover, for other formulations based on SpfrNPV, as those developed with isolates from Nicaragua and the United States (3AP2), which have been evaluated in maize crops in Mexico, Honduras and Tanzania, the recommended application doses range between $1.2 \times 10^{12}$ and $6 \times 10^{12} \mathrm{OBs} /$ ha $[45,46]$, which are between $33 \%$ to $43 \%$ higher than the dose selected in this work for the biopesticide based in the mixture M3.

\section{Conclusions}

The results of this study demonstrated the enhancer activity of SpfrGV over the insecticidal activity of SpfrNPV. The low GV:NPV ratio in mixture M3 (97.5\% of SpfrNPV and $2.5 \%$ of SpfrGV) exhibited the maximum enhancer potential by increasing the pathogenicity 9.92 times. This effect could be related with some proteins encoded by the Colombian isolate VG008 that are involved in the midgut infection. The mixture M3 was selected to develop a new and more efficient biopesticide to control the fall armyworm by applying lower doses in the field, helping to overcome the technical and economic limitations of baculovirus-based products and improving its economic feasibility.

\section{Patents}

Virus based biopesticide: Invention patent requested for United States, No. 15387565 [47].

Author Contributions: P.E.C.-O. and L.F.V.-R. conceived the work, designed experiment methodologies and carried out statistical analysis and results interpretation. G.P.B.-C. contributed with experiment methodologies and scanning electron microscopy. P.E.C.-O., A.E.R., and J.A.G.-V. conducted the experiments. P.E.C.-O. wrote the first manuscript and J.A.G.-V., A.E.R., G.P.B.-C., and L.F.V.-R. contributed to results discussion and paper corrections.

Funding: This work was supported by grants from the Colombian Ministry of Agriculture and Rural Development (MADR), Colombian Corporation of Agricultural Research (Agrosavia), Curiosity Funds from AgResearch Ltd. and a Ph.D. scholarship from Colciencias (Colombia) grant number 528-2011/52818316.

Acknowledgments: The authors thank Claudia Milena Mesa, Jhon Pablo Vargas and Consuelo Rojas (Corporación Colombiana de Investigación Agropecuaria, Agrosavia) for the support in bioassays development and S. frugiperda rearing.

Conflicts of Interest: The authors declare no conflict of interest.

\section{References}

1. ICA (Instituto Colombiano Agropecuario). Resolución No. 000879 (25 Marzo 2008). Available online: https://www.ica.gov.co/getattachment/29ca37cc-b101-438e-8251-4803a18203cc/2008R0879.aspx (accessed on 28 May 2019).

2. Lapied, B.; Pennetier, C.; Apaire-Marchais, V.; Licznar, P.; Corbel, V. Innovative applications for insect viruses: Towards insecticide sensitization. Trends Biotechnol. 2009, 27, 190-198. [CrossRef] [PubMed] 
3. Harrison, R.L.; Herniou, E.A.; Jehle, J.A.; Theilmann, D.A.; Burand, J.P.; Becnel, J.J.; Krell, P.J.; van Oers, M.M.; Mowery, J.D.; Bauchan, G.R.; et al. ICTV Virus Taxonomy Profile: Baculoviridae. J. Gen. Virol. 2018, 99, 1185-1186. [CrossRef] [PubMed]

4. Martínez, A.-M.; Pineda, S.; Figueroa, J.I.; Chavarrieta, J.M.; Williams, T. Los baculovirus como bioinsecticidas: Evaluación de un nucleopoliedrovirus para el combate de Spodoptera frugiperda (Lepidoptera: Noctuidae) en México y Honduras. Cienc. Nicolaita 2012, 56, 35-47.

5. Behle, R.W.; Popham, H.J. Laboratory and field evaluations of the efficacy of a fast-killing baculovirus isolate from Spodoptera frugiperda. J. Invertebr. Pathol. 2012, 109, 194-200. [CrossRef] [PubMed]

6. Gómez, J.; Guevara, J.; Cuartas, P.; Espinel, C.; Villamizar, L. Microencapsulated Spodoptera frugiperda nucleopolyhedrovirus: Insecticidal activity and effect on arthropod populations in maize. Biocontrol Sci. Technol. 2013, 23, 829-846. [CrossRef]

7. Slavicek, J. Baculovirus enhancins and their role in viral pathogenicity. In Molecular Biology; Adoga, M.P., Ed.; IntechOpen: Rijeka, Croatia, 2012; pp. 147-168.

8. Gómez Valderrama, J.A.; Guevara Agudelo, E.J.; Barrera Cubillos, G.P.; Cotes Prado, A.M.; Villamizar Rivero, L.F. Aislamiento, identificación y caracterización de nucleopoliedrovirus nativos de Spodoptera frugiperda en Colombia. Rev. Fac. Nac. Agron. Medellín 2010, 63, 5511-5520.

9. Cuartas, P.; Barrera, G.; Barreto, E.; Villamizar, L. Characterisation of a Colombian granulovirus (Baculoviridae: Betabaculovirus) isolated from Spodoptera frugiperda (Lepidoptera: Noctuidae) larvae. Biocontrol Sci. Technol. 2014, 24, 1265-1285. [CrossRef]

10. Barrera, G.P.; Belaich, M.N.; Patarroyo, M.A.; Villamizar, L.F.; Ghiringhelli, P.D. Evidence of recent interspecies horizontal gene transfer regarding nucleopolyhedrovirus infection of Spodoptera frugiperda. BMC genomics 2015, 16, 1008. [CrossRef]

11. Cuartas, P.E.; Barrera, G.P.; Belaich, M.N.; Barreto, E.; Ghiringhelli, P.D.; Villamizar, L.F. The complete sequence of the first Spodoptera frugiperda Betabaculovirus genome: A natural multiple recombinant virus. Viruses 2015, 7, 394-421. [CrossRef]

12. Toprak, U.; Harris, S.; Baldwin, D.; Theilmann, D.; Gillott, C.; Hegedus, D.D.; Erlandson, M.A. Role of enhancin in Mamestra configurata nucleopolyhedrovirus virulence: Selective degradation of host peritrophic matrix proteins. J. Gen. Virol. 2012, 93, 744-753. [CrossRef]

13. Salvador, R.; Ferrelli, M.L.; Sciocco-Cap, A.; Romanowski, V. Analysis of a chitinase from EpapGV, a fast killing betabaculovirus. Virus Genes 2014, 48, 406-409. [CrossRef] [PubMed]

14. Greene, G.L.; Leppla, N.; Dickerson, W.A. Velvetbean Caterpillar: A Rearing Procedure and Artificial Medium. J. Econ. Entomol. 1976, 69, 487-488. [CrossRef]

15. Hughes, P.R.; Wood, H.A. A synchronous peroral technique for the bioassay of insect viruses. J. Invertebr. Pathol. 1981, 37, 154-159. [CrossRef]

16. Bullock, J.; Crawley, M.J. GLIM for Ecologists; Wiley-Blackwell: Hoboken, NJ, USA, 1994; Volume 31, p. 402.

17. Zar, J. Biostatistical Analysis, 5th ed.; Prentice-Hall, Inc.: Upper Saddle River, NJ, USA, 2007.

18. Cuartas, P.E.; Villamizar, L.F.; Barrera, G.P.; Ruiz, J.C.; Campos, J.C.; Leon-Martinez, G.; Gomez-Valderrama, J. Novel biopesticide based on Erinnyis ello betabaculovirus: Characterization and preliminary field evaluation to control Erinnyis ello in rubber plantations. Pest Manag. Sci. 2019, 75, 1391-1399. [CrossRef] [PubMed]

19. Quiroga, I.; Gómez, M.; Villamizar, L. Estabilidad de formulaciones a base de granulovirus para controlar Teci solanivora (Lepidotera: Gelechiidae) en campo. Rev. Colomb. Entomol. 2011, 37, 27-35.

20. Villamizar, L.; Barrera, G.; Cotes, A.M.; Martínez, F. Eudragit S100 microparticles containing Spodoptera frugiperda nucleopolyehedrovirus: Physicochemical characterization, photostability and in vitro virus release. J. Microencapsul. 2010, 27, 314-324. [CrossRef] [PubMed]

21. Barrera, G. SDS-PAGE of GVPs from SpfrGV VG008. Corporación Colombiana de Investigación Agropecuaria-Agrosavia. 2019; (not intended for publication).

22. Ravensberg, W. A Roadmap to the Successful Development and Commercialization of Microbial Pest Control Products for Control of Arthropods; Springer: Berlin, Germany, 2011.

23. Guo, H.F.; Fang, J.C.; Wang, J.P.; Zhong, W.F.; Liu, B.S. Interaction of Xestia c-nigrum granulovirus with peritrophic matrix and Spodoptera litura nucleopolyhedrovirus in Spodoptera litura. J. Econ. Entomol. 2007, 100, 20-25. [CrossRef] 
24. Hayakawa, T.; Shimojo, E.-I.; Mori, M.; Kaido, M.; Furusawa, I.; Miyata, S.; Sano, Y.; Matsumoto, T.; Hashimoto, Y.; Granados, R.R. Enhancement of baculovirus infection in Spodoptera exigua (Lepidoptera: Noctuidae) larvae with Autographa californica nucleopolyhedrovirus or Nicotiana tabacum engineered with a granulovirus enhancin gene. J. Appl. Entomol. Z. 2000, 35, 163-170. [CrossRef]

25. Mukawa, S.; Goto, C. Mamestra brassicae nucleopolyhedrovirus infection and enhancing effect of proteins derived from Xestia c-nigrum granulovirus in larvae of Mamestra brassicae and Helicoverpa armigera (Lepidoptera: Noctuidae) on cabbage. J. Econ. Entomol. 2010, 103, 257-264. [CrossRef]

26. Mukawa, S.; Goto, C. Enhancement of nucleopolyhedrovirus infectivity against Mamestra brassicae (Lepidoptera: Noctuidae) by proteins derived from granulovirus and a fluorescent brightener. J. Econ. Entomol. 2007, 100, 1075-1083. [CrossRef]

27. Shapiro, M. Effect of two granulosis viruses on the activity of the gypsy moth (Lepidoptera: Lymantriidae) nuclear polyhedrosis virus. J. Econ. Entomol. 2000, 93, 1633-1637. [CrossRef] [PubMed]

28. Corsaro, B.G.; Gijzen, M.; Wang, P.; Granados, R. Baculovirus enhancing proteins as determinants of viral pathogenesis. In Parasites and Pathogens of Insects; Academic Press: New York, NY, USA, 1993; pp. 127-145.

29. Hoover, K.; Humphries, M.A.; Gendron, A.R.; Slavicek, J.M. Impact of viral enhancin genes on potency of Lymantria dispar multiple nucleopolyhedrovirus in L. dispar following disruption of the peritrophic matrix. J. Invertebr. Pathol. 2010, 104, 150-152. [CrossRef] [PubMed]

30. Goto, C.; Mukawa, S.; Mitsunaga, T. Two year field study to evaluate the efficacy of Mamestra brassicae nucleopolyhedrovirus combined with proteins derived from Xestia c-nigrum granulovirus. Viruses 2015, 7, 1062-1078. [CrossRef]

31. Biedma, M.E.; Salvador, R.; Ferrelli, M.L.; Sciocco-Cap, A.; Romanowski, V. Effect of the interaction between Anticarsia gemmatalis multiple nucleopolyhedrovirus and Epinotia aporema granulovirus, on A. gemmatalis (Lepidoptera: Noctuidae) larvae. Biol. Control 2015, 91, 17-21. [CrossRef]

32. Li, Z.; Li, C.; Yang, K.; Wang, L.; Yin, C.; Gong, Y.; Pang, Y. Characterization of a chitin-binding protein GP37 of Spodoptera litura multicapsid nucleopolyhedrovirus. Virus Res. 2003, 96, 113-122. [CrossRef]

33. Martemyanov, V.V.; Kabilov, M.R.; Tupikin, A.E.; Baturina, O.A.; Belousova, I.A.; Podgwaite, J.D.; Ilynykh, A.V.; Vlassov, V.V. The enhancin gene: One of the genetic determinants of population variation in baculoviral virulence. Dokl. Biochem. Biophys. 2015, 465, 351-353. [CrossRef] [PubMed]

34. Shapiro, M.; Preisler, H.K.; Robertson, J.L. Enhancement of baculovirus activity on gypsy moth (Lepidoptera: Lymantriidae) by chitinase. J. Econ. Entomol. 1987, 80, 1113-1116. [CrossRef]

35. Rao, R.; Fiandra, L.; Giordana, B.; de Eguileor, M.; Congiu, T.; Burlini, N.; Arciello, S.; Corrado, G.; Pennacchio, F. AcMNPV ChiA protein disrupts the peritrophic membrane and alters midgut physiology of Bombyx mori larvae. Insect Biochem. Mol. Biol. 2004, 34, 1205-1213. [CrossRef]

36. Hackett, K.; Boore, A.; Deming, C.; Buckley, E.; Camp, M.; Shapiro, M. Helicoverpa armigera granulovirus interference with progression of $H$. zea nucleopolyhedrovirus disease in H. zea larvae. J. Invertebr. Pathol. 2000, 75, 99-106. [CrossRef]

37. Ishimwe, E.; Hodgson, J.J.; Passarelli, A.L. Expression of the Cydia pomonella granulovirus matrix metalloprotease enhances Autographa californica multiple nucleopolyhedrovirus virulence and can partially substitute for viral cathepsin. Virology 2015, 481, 166-178. [CrossRef]

38. Tellam, R.L.; Wijffels, G.; Willadsen, P. Peritrophic matrix proteins. Insect Biochem. Mol. Biol. 1999, $29,87-101$. [CrossRef]

39. Barbehenn, R.V.; Martin, M.M. Peritrophic envelope permeability in herbivorous insects. J. Insect Physiol. 1995, 41, 303-311. [CrossRef]

40. Jenkins, N.E.; Grzywacz, D. Quality control of fungal and viral biocontrol agents - assurance of product performance. Biocontrol Sci. Techn. 2000, 10, 753-777. [CrossRef]

41. Slack, J.; Arif, B. The baculoviruses occlusion-derived virus: Virion structure and function. Adv. Virus Res. 2007, 69, 99-165. [PubMed]

42. Lasa, R.; Williams, T.; Caballero, P. Insecticidal properties and microbial contaminants in a Spodoptera exigua multiple nucleopolyhedrovirus (Baculoviridae) formulation stored at different temperatures. J. Econ. Entomol. 2008, 101, 42-49. [CrossRef]

43. Yang, M.M.; Li, M.L.; Zhang, Y.; Wang, Y.Z.; Qu, L.J.; Wang, Q.H.; Ding, J.Y. Baculoviruses and insect pests control in China. Afr. J. Microbiol. Res. 2012, 6, 214-218. 
44. Grzywacz, D.; Moore, S. Chapter 7-Production, formulation, and bioassay of baculoviruses for pest control. In Microbial Control of Insect and Mite Pests; Lacey, L.A., Ed.; Academic Press: Cambridge, MA, USA, 2017; pp. 109-124.

45. Martínez, A.M.; Goulson, D.; Chapman, J.W.; Caballero, P.; Cave, R.D.; Williams, T. Is it feasible to use optical brightener technology with a baculovirus bioinsecticide for resource-poor maize farmers in Mesoamerica? Biol. Control 2000, 17, 174-181. [CrossRef]

46. Castillejos, V.; Trujillo, J.; Ortega, L.D.; Santizo, J.A.; Cisneros, J.; Penagos, D.I.; Valle Mora, J.; Williams, T. Granular phagostimulant nucleopolyhedrovirus formulations for control of Spodoptera frugiperda in maize. Biol. Control. 2002, 24, 300-310. [CrossRef]

47. Virus based biopesticide: Invention patent requested for United States. Available online: https://patentimag es.storage.googleapis.com/a9/9f/3f/d8411d6cce024b/US20170172154A1.pdf (accessed on 28 May 2019).

(C) 2019 by the authors. Licensee MDPI, Basel, Switzerland. This article is an open access article distributed under the terms and conditions of the Creative Commons Attribution (CC BY) license (http://creativecommons.org/licenses/by/4.0/). 